\title{
New cultive medium for bioconversion of C5 fraction from sugarcane bagasse using rice bran extract
}

\author{
Debora Danielle Virginio da Silva*, Elisangela de Jesus Cândido, \\ Priscila Vaz de Arruda, Silvio Silvério da Silva, Maria das Graças de Almeida Felipe \\ Departmento de Biotecnologia, Escola de Engenharia de Lorena, Universidade de São Paulo, \\ Lorena, SP, Brazil.
}

Submitted: September 21, 2013; Approved: June 6, 2014

\begin{abstract}
The use of hemicellulosic hydrolysates in bioprocesses requires supplementation as to ensure the best fermentative performance of microorganisms. However, in light of conflicting data in the literature, it is necessary to establish an inexpensive and applicable medium for the development of bioprocesses. This paper evaluates the fermentative performance of Scheffersomyces (Pichia) stipitis and Candida guilliermondii growth in sugarcane bagasse hemicellulosic hydrolysate supplemented with different nitrogen sources including rice bran extract, an important by-product of agroindustry and source of vitamins and amino acids. Experiments were carried out with hydrolysate supplemented with rice bran extract and $\left(\mathrm{NH}_{4}\right)_{2} \mathrm{SO}_{4}$; peptone and yeast extract; $\left(\mathrm{NH}_{4}\right)_{2} \mathrm{SO}_{4}$, peptone and yeast extract and non-supplemented hydrolysate as a control. S. stipitis produced only ethanol, while C. guilliermondii produced xylitol as the main product and ethanol as by-product. Maximum ethanol production by $S$. stipitis was observed when sugarcane bagasse hemicellulosic hydrolysate was supplemented with $\left(\mathrm{NH}_{4}\right)_{2} \mathrm{SO}_{4}$, peptone and yeast extract. Differently, the maximum xylitol formation by $C$. guilliermondii was obtained by employing hydrolysate supplemented with $\left(\mathrm{NH}_{4}\right)_{2} \mathrm{SO}_{4}$ and rice bran extract. Together, these findings indicate that: a) for both yeasts $\left(\mathrm{NH}_{4}\right)_{2} \mathrm{SO}_{4}$ was required as an inorganic nitrogen source to supplement sugarcane bagasse hydrolysate; b) for S. stipitis, sugarcane hemicellulosic hydrolysate must be supplemented with peptone and yeast extract as organic nitrogen source; and: c) for $C$. guilliermondii, it must be supplemented with rice bran extract. The present study designed a fermentation medium employing hemicellulosic hydrolysate and provides a basis for studies about value-added products as ethanol and xylitol from lignocellulosic materials.
\end{abstract}

Key words: Candida guilliermondii, hemicellulosic hydrolysate, Scheffersomyces stipitis, rice bran extract, sugarcane bagasse.

\section{Introduction}

Lignocellulosic biomass, one of the most abundant feedstock to be used in bioprocesses, consists of three main components: cellulose (35-50\% dry weight), hemicellulose (20-35\% of dry weight) and lignin (10-25\% of dry weight). Cellulose is a linear polymer of glucose units linked by $\beta$-1.4-glucosidic bonds. Unlike cellulose, hemicellulose is a heterogeneous polymer primarily constituted of pentoses (xylose, arabinose), hexoses (mannose, glucose, galactose) and sugar acids, with D-xylose as the major sugar after hydrolysis (Saha, 2003).

Annually, about $570 \times 10^{6}$ tons of sugar cane are harvested in Brazil (Conab, 2012) and sugar mills generate approximately $270-280 \mathrm{~kg}$ of bagasse $(50 \%$ moisture) per metric ton of sugarcane (Souza and Macedo, 2010). Although this by-product produced in the sugar and ethanol industry has been currently used as a fuel for the generation of steam and electricity (Rudolf et al., 2008), a surplus of this bagasse has a potential for the conversion to biofuels and chemicals in biorefinery. However, its use requires a 
treatment of bagasse fibers in order to extract fermentable sugars.

Hydrolysis is required for the conversion of the lignocellulosic polysaccharides into fermentable sugars (Cardona et al., 2010). At this moment, the most frequently employed hydrolysis technology is the one which utilizes diluted sulphuric acid due to its low cost (Shatalov and Pereira, 2012). The liquid phase from the hydrolysis reaction - containing xylose and other hemicellulosic monosaccharides as well as other compounds derived from lignin - can then be utilized in bioconversion (Jeffries and Jin, 2000).

According to Lynd et al. (1999), the conversion of xylose into value-added chemicals such as xylitol, ethanol, and lactic acid, is attractive to the fermentation industry. In particular, the biotechnological obtainment of xylitol and ethanol has been studied during the last decade because xylitol can be used as a functional sweetener (Edelstein et $a l ., 2007)$ and ethanol is a clean biofuel derived from a renewable source, which is an alternative to the ever reducing fossil fuels (Cerveró et al., 2010).

It is known that xylose metabolism can result in the production of xylitol and ethanol depending on the microorganism used in the process. Candida guilliermondii was described as a very effective xylitol producer (Felipe et al., 1997; Silva and Felipe, 2006), since it has the capacity to synthesize two key enzymes in the xylose metabolism: NADPH-dependent xylose reductase and $\mathrm{NAD}^{+}$-dependent xylitol dehydrogenase. The former reduces xylose to xylitol and the latter oxidizes xylitol to xylulose and both are induced by xylose (Rosa et al., 1998, Sene et al., 2001).

In ethanol production, among the xylose-fermenting yeasts, Scheffersomyces (Pichia) stipitis has been considered likely to turn out well for industrial applications due to its ability to ferment xylose with a high ethanol yield. Besides, $P$. stipitis has no absolute vitamin requirements for xylose fermentation and is able to ferment a wide range of sugars (Agbogbo et al., 2006).

Specifically regarding the use of lignocellulosic hydrolysates in bioprocesses, such as fermentation of pentoses, an adequate nitrogen supplementation is very important to cell growth, and since hemicellulosic hydrolysates contain, in addition to sugars, other constituents such as phenolic compounds and metallic ions, which exert an inhibitory effect on enzymatic activities affecting the fermentative performance (Watson et al., 1984, Pereira et al., 2011 ,), an adequate nutrient supplementation of the medium could reduce or avoid these negative effects.

However, there are conflicting data in literature about the best nutrient to supplement lignocellulosic hydrolysates to be used as fermentation medium. When hydrolysates are employed as a fermentative medium, inorganic and organic sources of nitrogen are typically used such as ammonium sulfate and peptone or malt extract and yeast extract, respectively (Silva et al., 2007, Schirmer-Mitchel et al.,
2008). Other authors have reported the use of yeast extract and urea (Ferreira et al., 2011). An alternative nitrogen source is the rice bran a residue of rice milling which contains amino acids, vitamins, proteins and minerals (Miller and Churchill, 1986). According to Silva et al. (2003) and Chaud et al. (2009), sugarcane bagasse hydrolysate supplemented with rice bran extract improved microbial growth and xylitol production by $C$. guilliermondii.

The purpose of this study was to establish a new fermentation medium employing sugarcane bagasse hydrolysate supplemented with nitrogen sources, including rice bran extract to improve the fermentative performance of C. guilliermondii and S. stipitis.

\section{Materials and Methods}

\section{Microorganisms and inoculum preparation}

The experiments were performed with C. guilliermondii FTI 20037 and Scheffersomyces (Pichia) stipitis NRRL Y-7124 (reclassification described by Kurtzman et al., 2011) maintained at $4{ }^{\circ} \mathrm{C}$ on malt-extract agar slants. A loopful of cells grown on a malt-extract agar slant was transferred to the medium used for inoculum preparation containing xylose $(30.0 \mathrm{~g} / \mathrm{L})$, rice bran extract $(20.0 \mathrm{~g} / \mathrm{L}),\left(\mathrm{NH}_{4}\right)_{2} \mathrm{SO}_{4}(2.0 \mathrm{~g} / \mathrm{L})$ and $\mathrm{CaCl}_{2} .2 \mathrm{H}_{2} \mathrm{O}(0.1 \mathrm{~g} / \mathrm{L})$. Erlenmeyer flasks $(125 \mathrm{~mL})$, containing $50 \mathrm{~mL}$ medium each, were incubated on a rotary shaker $(200 \mathrm{rpm})$ at $30^{\circ} \mathrm{C}$ for $24 \mathrm{~h}$. Afterwards, the cells were separated by centrifugation (2000 x g; $20 \mathrm{~min}$ ), rinsed twice with distilled water, and then the cell pellet was once again suspended in an adequate volume of distilled water. The initial cell concentration for all experiments was around $1.0 \mathrm{~g} / \mathrm{L}$.

\section{Preparation of the bagasse hydrolysate}

Sugarcane bagasse was hydrolyzed in a $350 \mathrm{~L}$ steel reactor at $121{ }^{\circ} \mathrm{C}$ for $20 \mathrm{~min}$ with $\mathrm{H}_{2} \mathrm{SO}_{4}$ at $1: 10 \mathrm{solid} /$ liquid ratio (100 mg of $\mathrm{H}_{2} \mathrm{SO}_{4}$ per gram of dry matter). The hydrolysate was first filtered and concentrated at $70{ }^{\circ} \mathrm{C}$ under vacuum to obtain a threefold increase in the xylose content. Afterwards, the hydrolysate was submitted to detoxification procedure in order to reduce toxic compounds concentration. It was submitted to a $\mathrm{pH}$ adjustment treatment, initially to 7.0 with $\mathrm{CaO}$ (commercial grade) and then to 2.5 with $\mathrm{H}_{3} \mathrm{PO}_{4}$, followed by the addition of $1.0 \%(\mathrm{w} / \mathrm{v})$ activated charcoal (refined powder), for $30 \mathrm{~min}$ under agitation $\left(100 \mathrm{rpm}, 60{ }^{\circ} \mathrm{C}\right)$. The precipitate formed as a result of this treatment was removed by vacuum filtration (Marton et al., 2006), and then the hydrolysate was autoclaved at $110^{\circ} \mathrm{C}$, under $0.5 \mathrm{~atm}$, in order to be used as the fermentation medium.

\section{Preparation of the rice bran extract}

The solution of rice bran extract was prepared by mixing $200 \mathrm{~g}$ of rice bran with $1.0 \mathrm{~L}$ distilled $\mathrm{H}_{2} \mathrm{O}$, 
autoclaved at $110^{\circ} \mathrm{C}(0.5 \mathrm{~atm})$, for $15 \mathrm{~min}$. Afterwards, the solids were separated by centrifugation ( $2000 \mathrm{x}$ g; $20 \mathrm{~min}$ ).

\section{Medium and fermentation conditions}

For fermentation medium preparation, concentrated and treated sugarcane bagasse hemicellulosic hydrolysate $(45.0 \mathrm{~g} / \mathrm{L}$ of xylose, $1.0 \mathrm{~g} / \mathrm{L}$ of glucose; $3.5 \mathrm{~g} / \mathrm{L}$ of arabinose, $2.5 \mathrm{~g} / \mathrm{L}$ of acetic acid, $0.0037 \mathrm{~g} / \mathrm{L}$ of furfural and $0.69 \mathrm{~g} / \mathrm{L}$ of total phenolic compounds) was supplemented with different nitrogen sources: $\mathrm{H} 1: 20.0 \mathrm{~g} / \mathrm{L}$ of rice bran extract, $2.0 \mathrm{~g} / \mathrm{L}$ of $\left(\mathrm{NH}_{4}\right)_{2} \mathrm{SO}_{4}$ and $0.1 \mathrm{~g} / \mathrm{L}$ of $\mathrm{CaCl}_{2} .2 \mathrm{H}_{2} \mathrm{O}$; $\mathrm{H} 2$ : $5.0 \mathrm{~g} / \mathrm{L}$ of peptone and $3.0 \mathrm{~g} / \mathrm{L}$ of yeast extract; H3: $2.0 \mathrm{~g} / \mathrm{L}$ of $\left(\mathrm{NH}_{4}\right)_{2} \mathrm{SO}_{4}, 5.0 \mathrm{~g} / \mathrm{L}$ of peptone, $3.0 \mathrm{~g} / \mathrm{L}$ of yeast extract and $0.1 \mathrm{~g} / \mathrm{L}$ of $\mathrm{CaCl}_{2} \cdot 2 \mathrm{H}_{2} \mathrm{O}$. Control experiment employing non-supplemented hydrolysate (H4) was also performed. The fermentative performance was evaluated in $125 \mathrm{~mL}$ Erlenmeyer flasks containing $50 \mathrm{~mL}$ of medium fermentation with initial $\mathrm{pH}$ adjusted to 5.5 (optimum $\mathrm{pH}$ for $C$. guilliermondii and P. stipitis), at $200 \mathrm{rpm}, 30^{\circ} \mathrm{C}$ for $72 \mathrm{~h}$. Experiments were carried out in duplicate.

\section{Analytical methods}

Xylose, glucose, arabinose, xylitol, ethanol, glycerol and acetic acid concentrations were determined by HPLC (Waters, Milford, MA) with a refraction index detector on a Bio-Rad Aminex HPX-87H at $45^{\circ} \mathrm{C}$, with $0.01 \mathrm{~N} \mathrm{H}_{2} \mathrm{SO}_{4}$ as the eluent at $0.6 \mathrm{~mL} \mathrm{~min}^{-1}$ flow rate. A Hewlett-Packard RP 18 column at $25{ }^{\circ} \mathrm{C}$ with acetonitrile: water (1:8) and $1 \%$ acetic acid as the eluent, and a $0.8 \mathrm{~mL} / \mathrm{min}$ flow rate was employed for the determination of furfural and hydroxymethylfurfural concentrations in a visible ultraviolet-light detector (SPD-10 $\left.{ }^{\mathrm{A}} \mathrm{UV}-\mathrm{VIS}\right)$. The total phenolic compounds concentration was estimated by ultraviolet spectroscopy at $280 \mathrm{~nm}$ (Villarreal et al., 2006). Cell growth was monitored by measuring absorbance at $600 \mathrm{~nm}$ (Beckman-DU 640B spectrophotometer). Cell concentration was calculated based on the relation of optical density and cell dry weight through a calibration curve.

\section{Results and Discussion}

\section{Sugar consumption and cell growth}

The influence of different nitrogen sources added in sugarcane bagasse hemicellulosic hydrolysate (H1: $\left(\mathrm{NH}_{4}\right)_{2} \mathrm{SO}_{4}$ and rice bran extract; $\mathrm{H} 2$ : peptone and yeast extract; $\mathrm{H} 3$ : $\left(\mathrm{NH}_{4}\right)_{2} \mathrm{SO}_{4}$, peptone and yeast extract; $\mathrm{H} 4$ : non-supplemented) on xylose consumption and biomass formation by $S$. stipitis and $C$. guilliermondii during fermentations are shown in Figure 1.

When S. stipitis was grown in the presence of peptone and yeast extract ( $\mathrm{H} 2$ and $\mathrm{H} 3$ ), total xylose consumption was observed corresponding to an improvement of $45 \%$ in comparison with hydrolysate without supplementation (H4). In H1 xylose consumption was around 90\%. Differently, for C. guilliermondii the maximum xylose consump- tion (99\%) was observed in hydrolysate supplemented with $\left(\mathrm{NH}_{4}\right)_{2} \mathrm{SO}_{4}$ and rice bran extract $(\mathrm{H} 1)$, indicating that rice bran extract contributes as a nitrogen source, since it contains amino acids, vitamins, proteins and minerals (Miller and Churchill, 1986, Chaud et al., 2009).

Regardless of the nitrogen source employed, glucose was $100 \%$ consumed within $24 \mathrm{~h}$ of fermentation for both yeasts. Unlike glucose consumption, the nitrogen source employed did not have any appreciable effect on arabinose assimilation, independently of the yeasts. The assimilation of this sugar (less than 50\%) was slow (data not shown). Low arabinose consumption was also reported by other authors using P. stipitis (Canilha et al., 2010) and C. guilliermondii (Silva et al., 2004) yeasts grown in sugarcane bagasse hemicellulosic hydrolysate supplemented with calcium chloride, ammonium sulfate and rice bran extract.

The cell growth of S. stipitis was around $24-45 \%$ higher than the one observed for C. guilliermondii, regardless of the condition evaluated (Figure 1). Coincidentally, the utilization of peptone and yeast extract (H2) favored cell growth for both yeasts. Furthermore, for S. sitipitis, this same condition (H2) resulted in maximum xylose consumption as well (Figure 1). The results obtained confirm the importance of nitrogen supplementation in the media, since cell growth in the condition without supplementation (H4) was smaller than the one observed to other fermentations evaluated for both yeasts.

The utilization of acetic acid (over 70\%) was also verified simultaneously with sugars by $C$. guilliermondii and $S$. stipitis, independently of the nitrogen source employed in sugarcane hemicellulosic bagasse hydrolysate, which was accomplished by raising medium $\mathrm{pH}$ (Figure 2). It is possible that acetic acid has been used to cell growth while xylose would be utilized to xylitol or ethanol formation in C. guilliermondii and S. stipitis, respectively. Acetic acid assimilation by the same yeasts grown in sugarcane bagasse hemicellulosic hydrolysate was also reported by other authors (Lima et al., 2004, Silva et al., 2004, Canilha et al., 2010).

\section{Ethanol and xylitol production}

The effects of nitrogen sources on ethanol and xylitol production by $S$. stipitis and $C$. guilliermondii grown in sugarcane bagasse hemicellulosic hydrolysate are respectively presented in Figure 3.

Important increase in fermentation efficiency was achieved by supplementation of the medium with nitrogen source, since fermentations employing hydrolysate without nitrogen supplementation led to the lowest products formation, coinciding with the lowest xylose uptake and the lowest cell growth (Figure 1). Probably the absence of nitrogen content in this medium (H4) resulted in cellular stress, although no morphological alteration was observed for both yeasts. According to Martinez-Moreno et al. (2012), nitro- 

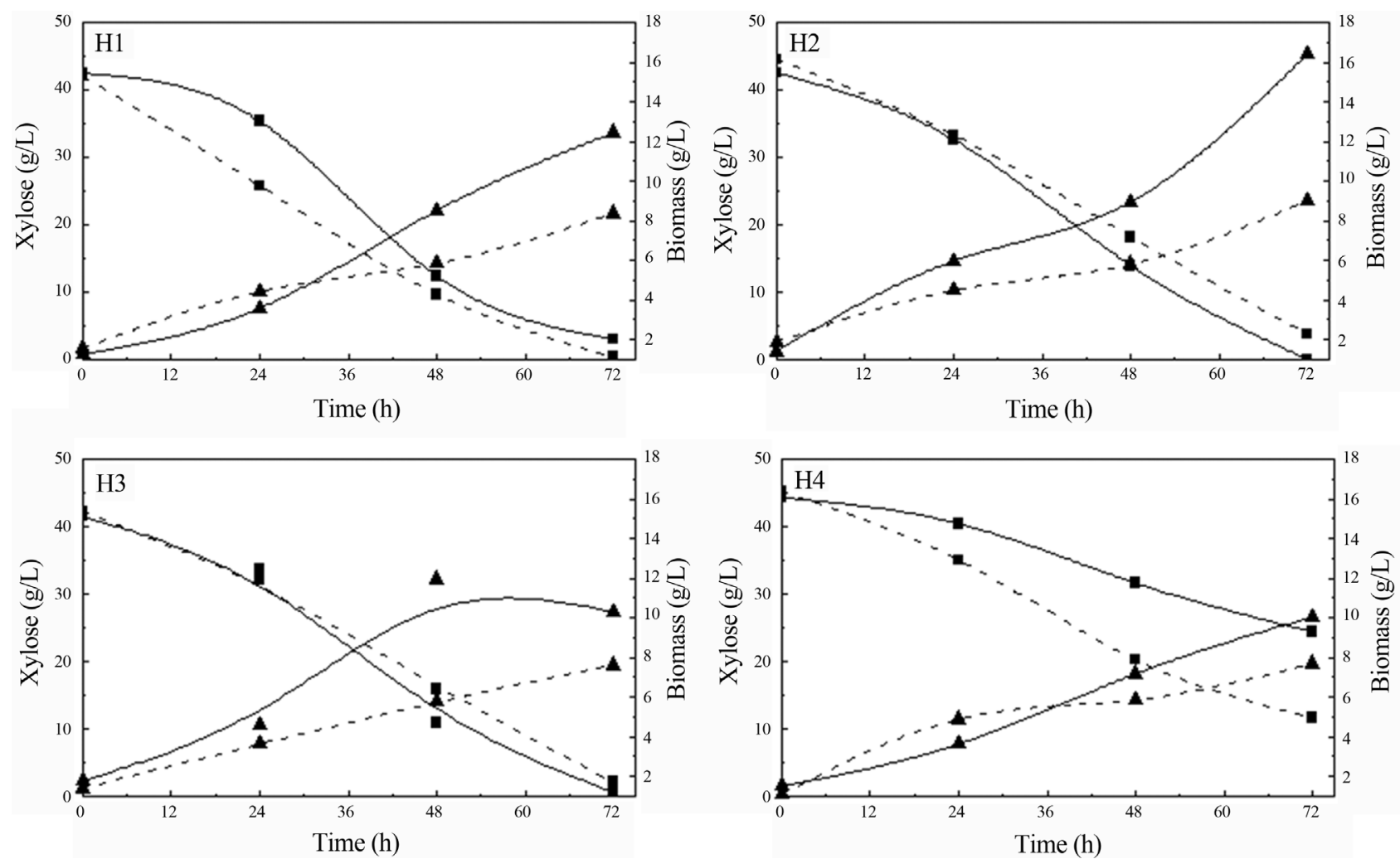

Figure 1 - Xylose consumption (square) and biomass formation (triangle) by S. stipitis (straight line) and C. guilliermondii (dash line) during fermentation of sugarcane bagasse hemicellulosic hydrolysate supplemented with different nitrogen sources (H1, H2, H3, H4).
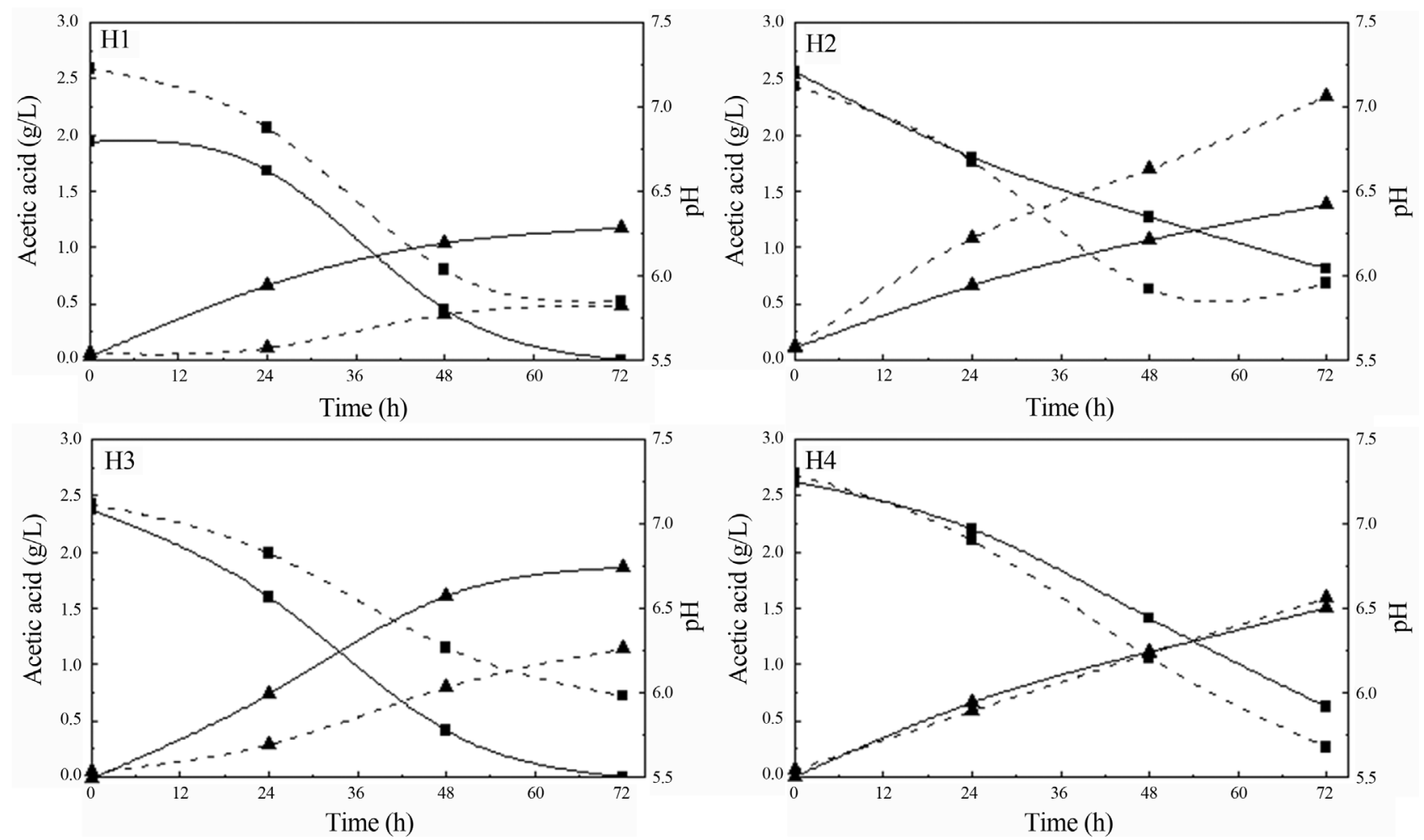

Figure 2 - Acetic acid consumption (square) and pH (triangle) during fermentation of sugarcane bagasse hydrolysate supplemented with different nutrients (H1, H2, H3, H4) by S. stipitis (straight line) and C. guilliermondii (dash line). 

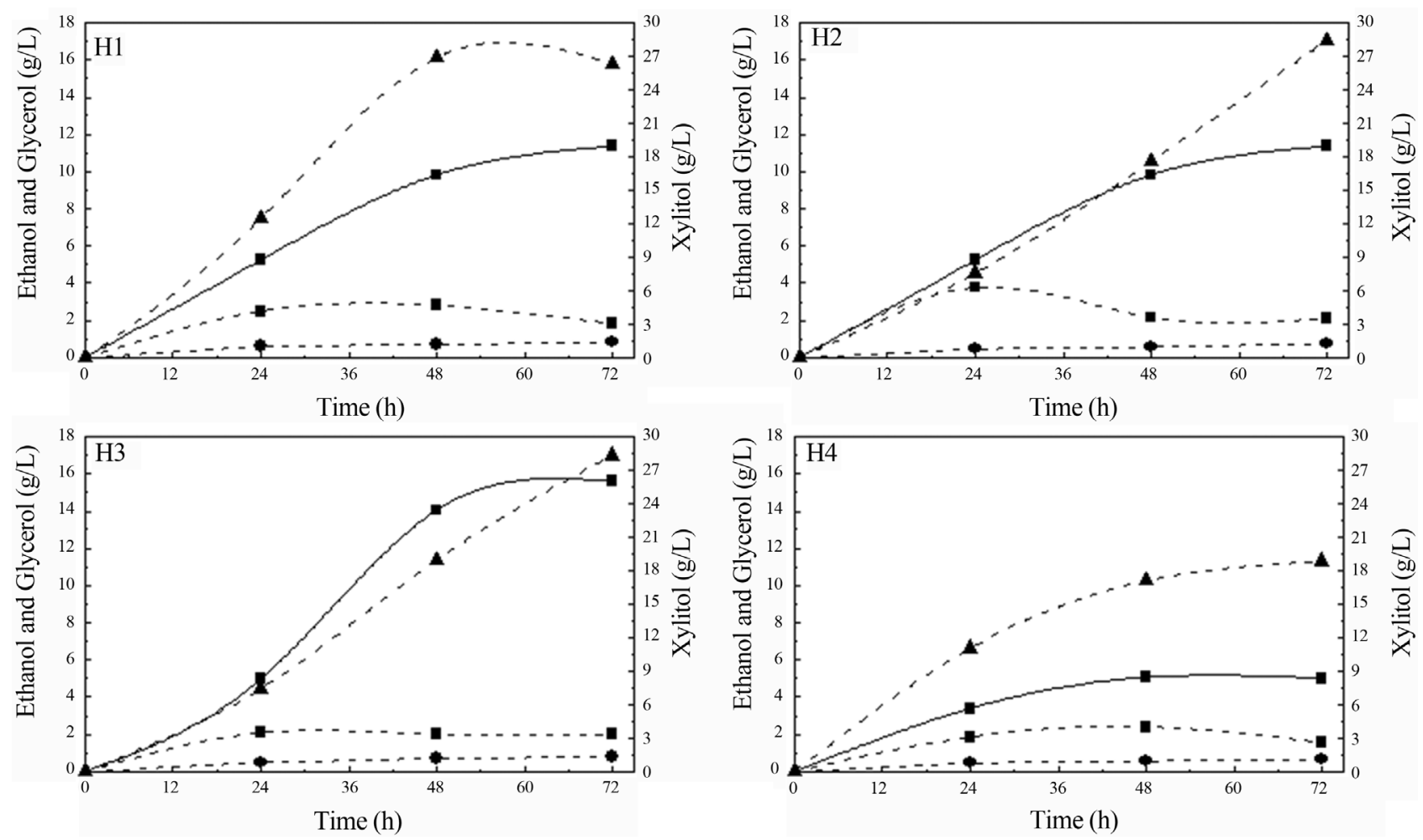

Figure 3 - Ethanol (square) xylitol (triangle) and glycerol (circle) concentrations during fermentation of sugarcane bagasse hemicellulosic hydrolysate supplemented with different nutrients $(\mathrm{H} 1, \mathrm{H} 2, \mathrm{H} 3, \mathrm{H} 4)$ by $\mathrm{S}$. stipitis (straight line) and C. guilliermondii (dash line).

gen limitation is one of the most common causes for slow fermentation.

For S. stipitis, maximum ethanol production (15.59 g/L) was observed when hydrolysate was supplemented with $\left(\mathrm{NH}_{4}\right)_{2} \mathrm{SO}_{4}$, peptone and yeast extract $(\mathrm{H} 3)$, corresponding to three-fold higher than that observed to hydrolysate non-supplemented. $\mathrm{H} 3$ condition was also resulted in the maximum values of $\mathrm{Y}_{\mathrm{P} / \mathrm{S}}(0.46 \mathrm{~g} / \mathrm{g})$ and $\mathrm{Q}_{\mathrm{P}}$ $(0.29 \mathrm{~g} / \mathrm{L} . \mathrm{h})$ obtained after $48 \mathrm{~h}$ of fermentation, corresponding to a xylose to ethanol efficiency conversion of $92 \%$. These results indicate that combination of inorganic $\left(\left(\mathrm{NH}_{4}\right)_{2} \mathrm{SO}_{4}\right)$ and organic (peptone and yeast extract) nitrogen sources improved both xylose consumption and ethanol production and this can be associated to the fact that yeast extract contains vitamins such as biotin, pyridoxine and folic acid that are not present in the rice bran extract (Miller and Churchill, 1986). Such results are in accordance with those reported by Agbogbo and Wegner (2006), who affirmed that ammonium salts increased the ethanol productivity in $P$. stipitis cultivated in synthetic medium.

It is important to mention that by-products were not formed during all fermentations employing S. stipitis. This is a good characteristic of this yeast intended for industrial applications as it ferments xylose rapidly with a high ethanol yield and apparently produces no by-products. According to Hahn-Hagerdal et al. (2007), not only all sugars on hydrolysate must be taken up and metabolized by the fer- menting organism but they must rather be converted into ethanol with minimal by-product formation.

For $C$. guilliermondii, the best nitrogen source to improve xylose to xylitol bioconversion was the combination of $\left(\mathrm{NH}_{4}\right)_{2} \mathrm{SO}_{4}$ and rice bran extract $(\mathrm{H1})$ (Figure 3). This condition resulted in maximum values of $\mathrm{Y}_{\mathrm{P} / \mathrm{S}}(0.83 \mathrm{~g} / \mathrm{g})$ and $\mathrm{Q}_{\mathrm{P}}(0.56 \mathrm{~g} / \mathrm{L} . \mathrm{h})$, observed after $48 \mathrm{~h}$ of fermentation, corresponding to xylose to xylitol conversion efficiency of $90.5 \%$. It was $98 \%$ higher than the efficiency conversion observed for fermentation of hydrolysate without supplementation (H4) and coincides with the one observed to xylose consumption. Differently, Mussatto and Roberto (2008) reported that when this same yeast was cultivated in brewer's spent grain hydrolysate, the supplementation of hydrolysate with nutrients (calcium chloride, ammonium sulfate and rice bran extract) did not interfere in xyloseto-xylitol conversion because xylitol production in this work did not require addition of nutrients to the medium, possibly due to differences in hydrolysate characteristics.

The formation of ethanol and glycerol by-products was also observed during $C$. guilliermondii growth, regardless of the evaluated conditions. The maximum ethanol concentration $(3.77 \mathrm{~g} / \mathrm{L})$ was observed using hydrolysate supplemented with peptone and yeast extract $(\mathrm{H} 2)$ and the maximum concentration of glycerol $(0.85 \mathrm{~g} / \mathrm{L})$ was observed in the hydrolysate supplemented with $\left(\mathrm{NH}_{4}\right)_{2} \mathrm{SO}_{4}$ and rice bran extract (H1). Ethanol and glycerol formation 
as by-products during fermentation sugarcane bagasse hemicellulosic hydrolysate by C. guilliermondii also was observed by other authors (Rodrigues et al., 2006, Silva et al., 2007). According to Neivogt and Stahl (1997), glycerol can play an important role in $\mathrm{NAD}^{+}$regeneration, which is necessary to maintain redox balance as well as to prevent the interruption of glycolysis. Thus, glycerol and ethanol formation by $C$. guiilliermondii may have been favorable to xylose-xylitol bioconversion because $\mathrm{NAD}^{+}$regeneration avoided NADH accumulation (Arruda and Felipe, 2009).

The fermentative performance of $S$. stipitis and $C$. guilliermondii grown in sugarcane bagasse hemicellulosic hydrolysate was dependent on the nitrogen source employed in the medium. An inorganic nitrogen source $\left(\left(\mathrm{NH}_{4}\right)_{2} \mathrm{SO}_{4}\right)$ was required for both yeasts. However, regarding the organic nitrogen source, different requirements were observed between the yeasts evaluated. $\left(\mathrm{NH}_{4}\right)_{2} \mathrm{SO}_{4}$ associated with yeast extract and peptone improved xylose to ethanol bioconversion by $S$. stipitis, resulting in the maximum xylose consumption and ethanol formation and no by-products were detected. For C. guilliermondii, the higher xylose consumption and xylitol formation were observed when hydrolysate was supplemented with $\left(\mathrm{NH}_{4}\right)_{2} \mathrm{SO}_{4}$ associated with rice bran extract which supplied the requirements of amino acids and vitamins. Furthermore, both yeasts were able to partially detoxify fermentation medium, since acetic acid consumption was observed. The relevance of this study is the formulation of a simple and inexpensive culture media mainly by employing rice bran extract, an agro-industrial residue. Furthermore, the results presented here are already being usefull in the development of other researches related to use of C5 fraction from lignocellulosic materials for production of bioproducts.

\section{Acknowledgments}

The authors gratefully acknowledge the financial support of CAPES, CNPq and FAPESP.

\section{References}

Agbogbo FK, Coward-Kelly G, Torry-Smith M et al. (2006) Fermentation of glucose/xylose mixtures using Pichia stipitis. Process Biochem 41:2333-2336.

Agbogbo FK, Wenger KS (2006) Effect of pretreatment chemicals on xylose fermentation by Pichia stipitis. Biotechnol Lett 28:2065-2069.

Arruda PV, Felipe MGA (2009) Role of glycerol addition on xylose-to-xylitol bioconversion by Candida guilliermondii. Curr Microbiol 58:274-278.

Canilha L, Carvalho W, Felipe MGA et al. (2010) Ethanol Production from sugarcane bagasse hydrolysate using Pichia stipitis. Appl Biochem Biotechnol 161:84-92.

Cardona CA, Quintero JA, Paz IC (2010) Production of bioethanol from sugarcane bagasse: Status and perspectives. Bioresour Technol 101:4754-4766.
Cerveró JM, Skovgaard PA, Felby C et al. (2010) Enzymatic hydrolysis and fermentation of palm kernel press cake for production of bioethanol. Enzyme Microbial Technol 46:177184.

Chaud LCS, Arruda PV, Felipe MGA (2009) Potencial do farelo de arroz para utilização em bioprocessos. Nucleus 6:33-46.

CONAB (2012) Acompanhamento de safra brasileira: Cana-deaçúcar, terceiro levantamento, dezembro/2011 - Companhia Nacional de Abastecimento. Available: http://www.conab.gov.br/OlalaCMS/uploads/arquivos/11_ 12_08_11_00_54_08.pdf, Accessed 25 July 2012.

Edelstein S, Smith K, Worthington A et al. (2007) Comparisons of six new artificial sweetener gradation ratios with sucrose in conventional-method cupcakes resulting in best percentage substitution ratios. J Culinary Sci Technol 5:61-74.

Felipe MGA, Vitolo M, Mancilha IM et al. (1997) Environmental parameters affecting xylitol production from sugar cane bagasse hemicellulosic hydrolysate by Candida guilliermondii. J Ind Microbiol Biotechnol 18:251-254.

Ferreira AD, Mussatto SI, Cadete RM et al. (2011) Ethanol production by a new pentose-fermenting yeast strain, Scheffersomyces stipitis UFMG-IMH 43.2, isolated from the Brazilian forest. Yeast 28:547-554.

Hahn-Hägerdal B, Karhumaa K, Fonseca C et al. (2007) Towards industrial pentose-fermenting yeast strains. Appl Microbiol Biotechnol 74:937-953.

Jeffries TW, Jin YS (2000) Metabolic engineering for improved fermentation of pentoses by yeasts. Adv Appl Microbiol 47:221-268.

Kurtzman CP, Fell JW, Boekhout T (2011) The Yeasts - A Taxonomic Study (Fifth edition) Elsevier, 2011.

Lima LHA, Felipe MGA, Vitolo M et al. (2004) Effect of acetic acid present in bagasse hydrolysate on the activities of xylose reductase and xylitol dehydrogenase in Candida guilliermondii. Appl Microbiol Biotechnol 65:734-738.

Lynd LR, Wyman CE, Gerngross TU (1999) Biocommodity. Eng Biotechnol 15:777-793.

Martínez-Moreno R, Morales P, Gonzalez R et al. (2012) Biomass production and alcoholic fermentation performance of Saccharomyces cerevisiae as a function of nitrogen source. FEMS Yeast Res 12:477-485.

Marton JM, Felipe MGA, Almeida e Silva JB et al. (2006) Evaluation of the activated charcoals and adsorption conditions used in the treatment of sugarcane bagasse hydrolysate for xylitol production. Braz J Chem Eng 23:9-21.

Miller TL, Churchill BW (1986) Substrates for large-scale fermentation. In Manual of industrial microbiology and biotechnology, Demain AL and Solomon NA. (eds.) American Society of Microbiology 130-131.

Mussatto SI, Roberto IC (2008) Establishment of the optimum initial xylose concentration and nutritional supplementation of brewer's spent grain hydrolysate for xylitol production by Candida guilliermondii. Process Biochem 43:540-546.

Neivogt E, Stahl U (1997) Osmoregulation and glycerol metabolism in the yeast Saccharomyces cerevisiae. FEMS Microbiol Rev 21:231-241.

Nigam JN (2001) Ethanol production from wheat straw hemicelluloses hydrolysate by Pichia stipitis. J Appl Microbiol 90:208-215.

Pereira RS, Mussatto SI, Roberto IC (2011) Inhibitory action of toxic compounds present in lignocellulosic hydrolysates on 
xylose to xylitol bioconversion by Candida guilliermondii. J Ind Microbiol Biotechnol 38:71-78.

Rodrigues RCLB, Sene L, Matos GS et al. (2006) Enhanced xylitol production by precultivation of Candida guilliermondii cells in sugarcane bagasse hemicellulosic hydrolysate. Bioresour Technol 99:2898-2904.

Rosa SMA, Felipe MGA, Silva SS et al. (1998) Xylose reductase production by Candida guilliermondii. Appl Biochem Biotechnol 70-72:127-135.

Rudolf A, Baudel H, Zacchi G et al. (2008) Simultaneous saccharification and fermentation of steam-pretreated bagasse using Saccharomyces cerevisiae TMB3400 and Pichia stipitis CBS6054. Biotechnol Bioeng 99:783-790.

Saha BC (2003) Hemicellulose bioconversion. J Ind Microbiol Biotechnol 30:279-291.

Schirmer-Michel AC, Flores SH, Hertz PF et al. (2008) Production of ethanol from soybean hull hydrolysate by osmotolerant Candida guilliermondii NRRL Y-2075. Bioresour Technol 99:2898-2904.

Sene L, Felipe MGA, Silva SS et al. (2001) Metabolic study of the adaptation of the yeast Candida guilliermondii to sugarcane bagasse hydrolysate. Appl Biochem Biotechnol 91-93:671-680.

Shatalov AA, Pereira H (2012) Xylose production from giant reed (Arundo donax L.): Modeling and optimization of dilute acid hydrolysis. Carbohydrate Polymers 87:210-217.

Silva DDV, Mancilha IM, Silva SS et al. (2007) Improvement of biotechnological xylitol production by glucose during cultive of Candida guilliermondii in sugarcane bagasse hydrolysate. Braz Arch Biology Technol 50:207-215.

Silva DDV, Felipe MGA (2006) Effect of glucose:xylose ratio on xylose reductase and xylitol dehydrogenase activities from Candida guilliermondii in sugarcane bagasse hydrolysate. J Chem Technol Biotechnol 81:1294-1300.
Silva DDV, Felipe MGA, Mancilha IM et al. (2004) Inhibitory effect of acetic acid on bioconversion of xylose in xylitol by Candida guilliermondii in sugarcane bagasse hydrolysate. Braz J Microbiol 35:248-254.

Silva DDV, Felipe MGA, Mancilha IM et al. (2003) Evaluation of the conditions used in the preparation of sugarcane bagasse hydrolysate for improvement of the xylitol production by fermentative process. In: XIV Simpósio Nacional de Fermentações SINAFERM 2003. Available: https://docs.google.com/viewer?a=v\&q=cache:f-ve6mzxPj gJ:www.enq.ufsc.br/eventos/sinaferm/trabalhos_completos /t257.doc+Evaluation + of + the + Conditions + Used + in + the + Preparation + of + Sugarcane + Bagasse+Hydrolysate+for+Improve-

ment + of + the + Xylitol+Production + . Accessed 12 July 2012.

Souza ELL, Macedo IC (2010) Etanol e bioeletricidade: A cana-de-açúcar no futuro da matriz energética, Luc Projetos de Comunicação, São Paulo, SP. Available: $\mathrm{http} / /$ www.google.com.br/url? sa=t\&rct=j\&q=\&esrc=s\&so urce $=$ web\&cd $=2 \&$ sqi $=2 \&$ ved $=$ 0CFoQFjAB\&url=http\%3A\%2F\%2Fwww.unica.com.br\%2Fdownload.asp\%3FmmdCode\%3D075B111F -8958-4E7A-9096-75CB07EFFAC6\&ei=IcPIT93dBane0g HGnbGTAQ\&usg=AFQjCNFMWdngyG9t1syQg3LpaQN Z6cjsdg. Accessed 12 July 2012.

Villarreal MLM, Prata AMR, Felipe MGA et al. (2006) Detoxification procedures of eucalyptus hemicellulose hydrolysate for xylitol production by Candida guilliermondii. Enzym Microbiol Technol 40:17-24.

Watson NE, Prior BA, Lategan PM (1984) Factors in acid treated bagasse inhibiting ethanol production from D-xylose by Pachysolen tannophilus. Enzyme Microbial Technol 6:451-456.

All the content of the journal, except where otherwise noted, is licensed under a Creative Commons License CC BY-NC. 